\title{
The story of mourning : rehashing or passing ? Hemiri Driss
}

PhD Student $4{ }^{\text {th }}$ Year under the Direction of Ms. Soraya Sbihi, Ibn Tofail University Kenitra, Morocco

Received: 25 Oct 2020; Received in revised form: 10 Nov 2020; Accepted: 17 Nov 2020; Available online: 17 Dec 2020

(C2020 The Author(s). Published by Infogain Publication. This is an open access article under the CC BY license (https://creativecommons.org/licenses/by/4.0/).

\begin{abstract}
Writing of mourning : is it possible to mourn in and through literature?
Death takes its ease in the literary text, indulges all linguistic fantasies and satisfies all the hopes of the author and the reader. Death is therefore for literature what it is for life: an indispensable obsession. The experience of grief is universal; that most people face at one time or another. But what makes it interesting for us is to analyze how it works in the following literary texts : Diary of a grieving mother by Salwa Tazi and Since my heart is dead by Maïssa Bey.

In this section we concern ourselves ons to the question of writing the grief of a child can be read through a literary experience. We wondered Rons this experience and tent er ons to understand since the writing of grief is highly personal in his testimony and suffering, reflecting a singular literary posture. The problematic is inscribed in these terms: what are the scriptural resources that make it possible to write about the death of a child and to account for the dynamics of the enterprise of "reconstruction "of the subject writing after the drama experienced?

Our analysis will therefore have as a common thread, that of showing the path of grief through the story, commenting on the symptoms and stages of grief experienced by the authors. This approach will offer an answer to the question : is it possible to mourn in and through writing? We therefore wonder how literature as such, through the work on language and on the emotions that it allows, generates a completely new and specific form of experience of mourning. This questioning raises the question of an approach and a constitution of the experience of mourning through and in the literature that would be quite distinct from other types of discourse or self-exposure. From there; legitimate questions arise : What form $(s)$ does this literature cover? What influence does this choice have on the treatment of bereavement in the work in question? Then, how can one hold a critical discourse which demands neutrality and reserve in the face of such intimate texts and which obviously arouse an empathy which could parasitize rigorous analysis?
\end{abstract}

Keywords - literature, mourning, novel, autobiography, rehashing, going beyond.

\section{Summary}

\section{Scripture of mourning: Is it possible to mourn in and through literature?}

Death takes its ease in the literary text, lets itself go to all linguistic fantasies and satisfies all the expectations of the author and the reader. Death is therefore for literature what it is for life: an indispensable obsession. The experience of mourning is universal; which is faced by most people one day or another. But what makes it interesting for us is to analyze how it works in the following literary texts: Diary of a mother in mourning for Salwa Tazi and Because my heart died of Maïssa Bey.
In this article we will focus on the question of writing the mourning of a child who reads through a literary experience. We will interrogate this experience and try to understand it to the extent that the writing of the mourning is eminently personal in its testimony and its suffering, thus reflecting a singular literary posture. The problem is as follows: what are the scriptural resources that make it possible to write about the death of a child and to report on the dynamics of the enterprise of "reconstruction" of the subject writing after the lived drama?

Our analysis will therefore have as a guideline, that of showing the path of mourning through the story, commenting on the symptoms and stages of mourning 
experienced by the authors. This approach will propose an answer to the question: Is it possible to grieve in and through writing? We therefore wonder why literature as such, through the work on language and the emotions it allows, engenders a form of experience of mourning that is quite new and specific. This interrogation raises the question of an approach and a constitution of the experience of mourning by and in the literature that would be quite distinct from other types of speech or selfexposure. Of the; legitimate questions are needed: What form (s) does this literature cover? What influence does this choice have on the treatment of grief in the work in question? Secondly, how can one hold a critical discourse that requires neutrality and reserve in the face of texts that are so intimate and which obviously give rise to empathy that could interfere with rigorous analysis?

Literature is the place where truths, beliefs and lies are expressed and transmitted. On his complaints manifests, his dice irs, her fantasies and her hopes. Literature is at times an individual expression anchored in a collective, but it is above all a collective perceived by an individual. In Literary Creation and the Waking Dream (1908), Freud hypothesized that literary creation relieves deep tensions, but he reduced this creation to the expression of fantasies in a satisfying aesthetic form. Of course, literary creation cannot be reduced, even if it is articulated in the unconscious, it is also the manifestation of a conscious relationship with the world, with texts and especially with its time. On the one hand, literature looks like a Spanish hostel where most of them only read what they plan and enjoy, on the other hand, it looks like a window open to the world and to oneself. If the speaking voice in the text targets the heart and the body, literature can become an inner experience, and therefore something in life can change. In this sense, literature is a care whether it is to read it, to write it or to make of it a first aid kit made up of maximsprescriptions and quotes-drugs to be used in case of need. It is a medicine, a treatment like music and art in general. The magic force of the word gives the possibility of expressing one's soul as well as the world in which one projects oneself. In fact, to write you have to distance yourself, take a step back, you also have to step away from the subject in order to see it from different angles. Jean-Phili ppe Miraux affirms that in the scriptural act resides a constant desire of the writer to return to life and to start all over again as if nothing had happened :

Writing is then what makes it possible to shed light on the path traveled; it is the instrument of updating; it arouses and promotes elucidation. Because behind the same person are hidden multiple personalities, uninterrupted stratifications of being and existing. (JeanPhilippe Miraux, autobiography, self-writing and sincerity. P.30)

Moreover, death takes its ease in the literary text, indulges in all linguistic fantasies and satisfies all the hopes of the author and the reader. Death is therefore for literature what it is for life: an indispensable obsession. The grieving experience is a universal one that most people face at one time or another. But what makes it interesting for us is to analyze how it works in the following literary texts:Diary of a grieving mother by Salwa Tazi and Since my heart is dead by Maïssa Bey. In this article we will focus on the question of writing the mourning of a child who gives himself to read through a literary experience. We will question this experience and try to understand it insofar as the writing of mourning is eminently personal in its testimony and its suffering, thus reflecting a singular literary posture. Q hat are so scriptural resources to write about the death of a child and to account for the dynamics of the company " reconstruction " of the subject after writing lived drama? Our analysis will therefore have as a common thread, that of showing the path of grief through the story, commenting on the symptoms and stages of grief experienced by the authors. This approach will offer an answer to the question: is it possible to mourn in and through writing? We therefore wonder how literature as such, through the work on language and on the emotions that it allows, generates a completely new and specific form of experience of mourning. This questioning raises the question of an approach and a constitution of the experience of mourning through and in the literature that would be quite distinct from other types of discourse or self-exposure. From there; the questio ns legitimate necessary qual (s) form (s) this literature she covers? And qual influence this choice in the treatment of mourning in the work in question ?

$\mathrm{L}$ is poetry, drama or the novel helps to feel stronger, purified, to live or at least survive. If we wish to retrace the history of this truth, we find ourselves obliged to start from Aristotle and his word " catharsis" to designate the strange capacity of tragedy to deliver the worst of passions. It is no doubt necessary to go back to the great therapeutic poems of Permenides, Heraclitus, Empedocles, and to all the lyric poetry of Greece. We must then descend step by step over time until today, stopping at length on writers such as Rabelais, Proust, Artaud, Roussel and others. While leafing through the diaries and diaries of writers often conceived as private therapy, and trying to 
distinguish the different medical virtues that we have been able to attribute to literature: against sadness, despair, suffering, loss, loneliness ...

Moreover, Martine Delfos shows in his book The elusive parent and 'Emergency 'é write (2000), as many writers have been hit by the death of their loved ones and have embarked on writing. Delfos established his research by focusing on the work of 146 writers who wrote between 1550 and 1950. Among the names mentioned are Mme de $\mathrm{S}$ é vign é, Jean-Jacques Rousseau, Charles Baudelaire, Valery Larbaud, St é phane Mallarm ed, George Sand, Marcel AYmed, Albert Camus, Fran ç ois Mauriac, Marguerite Yourcenar, Georges Perec and many ' others. We quickly notice that this list includes few women. Is it because the women did not speak out about mourning during this period? The women certainly had their own stories to tell, but few published. In the twentieth century, writers like Simone D e Beauvoir, Nathalie Sarraute and Marguerite Duras participated in the aesthetic and theoretical production of literary currents (Existentialism and the New novel), they imposed themselves in the ranks of the avant-garde. literary guard by highlighting the revaluation of women. The feminist movements of the 1970s forever changed the way we looked at female writing. The generation of writers who published from 1980 redefined their challenges and their forms of creation while taking into account the continuity with previous generations. Thus, writers began to write about their traumatic personal experiences, and beautiful texts have emerged: Place (1983) of 'Annie Ernaux black veil, (1992) of ' anny duperey, Gold (1997) of ' $\mathrm{H}$ é 1 è do Cixous in the roof slope (1998) to 'AnneMarie Garat, black coat (1998) Chantal Chawaf, dead Letter (1999) Linda L ê,An père so mystery é rieux (2001) by Nita Rousseau, and the list goes on. $\mathrm{C}$ es texts are part of a long list whose writers were at a time of their stories, a need to reset the grieving process. The actress Anny Duperey explains the need to take the scriptural act to tell a personal drama :

Curious to ê be so imp é riously pushed ed by the d é Sir of e write to say. To the point of not wanting anything else, refusing to do anything else. Attel e necessary to e write. [ ... ]. Hours to $t$ wirl enferm ed in itself, hide and seek with the feelings $[\ldots]$. Then there's' e card, it goes, of e courag ed, we return there because whatever we do need is Always at (Duperey, Anny.I will write . P.175)

For her part, Colette Nys-Mazure confirms that: "Words smooth, polish, police what was crude, unbearable, inhuman. Writing tries to make legible what was ISSN: 2456-7620 indecipherable" ( Nys-Mazure, Colette. The new child. P.9)

Of course, the writing of mourning has a price : it requires endless efforts, the writer comes up against silence and a blank page. The urge to say mourning is so powerful that writers are willing to give it effort.

In fact, over the past two decades, narrative production in the Maghreb, France and Quebec has revealed a great diversity of genres, themes and aesthetic processes. This did not prevent the existence of some points of convergence, including the difficult writing of mourning. A good number of writers, through an autobiographical or autofictive text, have given themselves to writing the " story of mourning " whether it is the death of the parents, the child or the close friend. Notably, many of these grief stories deal with the death of the child, which leads us to see a shift in the "grief paradigm" where the death of the parents is no longer the primary concern. Nevertheless, the concern for maternal mourning is also found in contemporary texts written by writers on both sides of the Atlantic. Grieving writers, in the painful experiences of loss, face thorny scriptural ethical and enunciative issues. These writers find themselves in a complex situation in which they face the need and urge to speak, as well as the difficulty of finding the right words. Jaques Derrida, in his many homage texts written following the death of his friends, refers to this paradoxical impasse [1]: the simple expression of the lack of adequate words and the simultaneous need to mourn and to break the silence which may prevail over everything. Even if the mourning is interminable, consolable, irreconcilable, it is nevertheless necessary to try to deepen it by the word :

However, the place of a survivor cannot be found. If ever we found this place, it would remain untenable, I would say almost deadly. And if it seemed tenable, this place, the word to be kept from this place would remain impossible. It is therefore untenable, this word. (Jacques Derrida, Each time unique, the end of the world, p. 240.)

Indeed, the fact of writing transforms, and constitutes an effort, sometimes painful, and a start in the process of mourning. Writing brings into existence and makes recognizable the thousand little ramifications of grief created by death : through the form that writing takes, grief in its " banal" character then becomes the object of recognition. It is a question of ensuring the mediation allowing to express, and to make exist ho rs of oneself a way of inhabiting a world colored by sorrow. For writers, 
the scriptural act is born essentially from lived experience, fiction is constructed as an extension of memory, because memory is not only a remedy against forgetting, but also a source of creation. It is clear that the desire for confession finds its finality through writing, which assumes a posture of catharsis by its tendency to throw out torments, sorrows and pains. El l e s located in the production of a narrative, a deliverance, and cease to be haunted e s by the loss and failure. Indeed, the expression " literature of mourning ", like the term " mourning ", refers directly to a content, it covers the loss of a loved one, the pain experienced and the time during which this mourning is experienced. As it indirectly refers to the possibility of "mourning " by resigning yourself to this loss. This way of seeing things reveals quite notable differences between the romantic genre and the autobiographical genre. In fact, the presence of " endless mourning " is verified in several novels, while the overcoming and repair are verifiable in the autobiographical genre. It is mainly through our corpus that this hypothesis will be examined. Of course, these texts present incontestable enunciative convergences. Above all, the writing of mourning is a writing in the first person, the narrator often addresses a recipient : the deceased in most cases. In Since My Heart Is Dead, written by Maïssa Bey, Aïda , the narrator writes to her murdered son in Algeria, this text takes on the appearance of an epistolary novel whose body of the story is presented in the form of a long and moving letter, through which she delivers an internal and subjective point of view, confiding to readers her anger, her frustrations, her feelings, her rebellion, her designs that she engraves in this notebook which has a structuring function. At around this novel both tragic and serene, Maïssa Bey depicts the inconsolable grief of a mother, all these mothers, these anonymous women who mourn in silence and despair the death of a child, 'a husband, a brother, a sister ... during the black decade in Algeria. For its part, Salwa Tazi addresses dan s, J ournal of a mother mourning, his late son. This diary traces the bitter experience a mother had after losing her child. It reveals the different facets of this crucifying ordeal from which she was able to come out brilliantly. A newspaper that moves and upsets by its real facts but also relieves and heals wounds, through words as simple as they are wise and soothing, having the power to help those who live the same pain, to overcome the insurmountable and to regain the strength to move forward.

In fact, the " I" is used in an expected way in the autobiography and in a less expected way in the novel, where the authors do not fail to refer to the time of writing and the role assigned to writing. Certainly, beyond these enunciative convergences, the novel reveals itself on the side of suffering and rehashing, and thus presents a mourning that is delicate to overcome, if not impossible. On the other hand, the autobiography seems to work for reparation and is revealed on the side of life. These differences can be clarified in the light of the specificity of these genres at the level of their writing and their reception.

\section{Pain in suffering in the novel}

In $P$ uisque mon coeur est mort, we find the classic signs of mourning : suffering, the feeling of being foreign to the world, of being a little dead, the desire to die. Thus, in this novel, sorrow is expressed by a form of generalized mourning and by an end marked by an impossible appeasement. The fragmentation is reflected in a tearing that affects the order of the story. In the letters addressed to her son, Aida returns several times to the first day of the funeral, divided into several intercalated chapters. First, she recounts in chapter four "First day" the first moments without her son:

I'll start by telling you how the first day went without you. I don't want to, I can't tell you about myself, tell you what I did or said when I opened the door to misfortune. [...] Fragments that I can neither identify nor put together .

( $\frac{\text { Maïssa Bey }}{\text { dead.P.22_23) }}$ ince my heart is

Then the narrator returns to this day of year the eleventh chapter "Madness ", where she tells the behavior of those relatives who do this ssaient to indicate the manner in which it must grieve .

The first evening, your aunt Halima, the enlightened one, the emeritus gossip as you call her, the one who has discovered herself a sacred mission and pours into a relentless proselytizing since her first pilgrimage to Mecca, crouched in front of me [...] Do you know that it is to show impiety to behave as you do? Be reasonable ; your behavior in these days of mourning is a serious attack on the precepts of our religion" ( Maïssa Bey . Since my heart is dead. p . 44 )

Once again, in the fourteenth chapter, she scrambles the order and takes us back to the first day, to pinpoint an important detail. In fact, she asks her son about the 
mysterious girl who came to mourn him on the day of the funeral :

Why didn't you tell me? Why haven't you told me about her? You never spoke her name in front of me. Not even the little hint. Why did she have to come into my life just the day you weren't there? [...] It is undoubtedly to say a last farewell to you that she had the strength to face all these glances on her, the foreigner, the unknown". ( Maïssa Bey. Because my heart is dead. P. 51$)$

The linear progression of the story does not seem to appear in a sequence animated by fragmentation. In the story, the writer leads the reader to previous events. In through "analepsis". This precisely amplifies this discontinuity in chronological order. The story ends with an end, in the chapter entitled " End " where the outcome of the revenge project held by Aïda is vague or even impenetrable. In fact, the prologue and epilogue form an e fate e swing fragment that announces the beginning and end. Indeed, they have the same idea: the death, the death of the son Nadir, and that of his best friend Hakim. The end $n$ ' is clear that through $\mathrm{c}$ e returns subtle between the epilogue and prologue.

Indeed, after having given signs of " narration exhaustion" such as preparations for the departure to the afterlife to join her murdered son, the narrator declares the end of the narration using several clues : " I hope no 'having forgotten nothing, for days and days, I examine point by point everything that remains for me to do.»(Maïssa Bey. Since my heart is dead. $\mathrm{P} 169$ )

A little later in the text, there is another clue " I would like this last evening to be sweet to us." » ( Maïssa Bey. Since my heart is dead. P176)

In fact, from page 176, the clues at the end begin to follow one another with the use of the adjective " last ", Aïda declares that she will put an end to the evenings she spent with her son rehashing her memories. and describe their emotions. She decides to take action and carry out her plan for revenge : to take the life of her son's murderer. In the $49^{\text {th }}$ track called " after " the narrator describes his condition after the murder, by suggesting she had accomplished his duty and that the story will end:" Then after that hand ...... who killed " ( Maïssa Bey. Because my heart is dead.p. 178$)$
The end of the diegesis is marked, in an explicit way, in the last title entitled " end ", the narrator describes the fateful moment by revealing that her hand was hijacked by Hakim (her son's best friend), thus the reader, confused, does not know if the mother has gone to the end of her quest. The epilogue of $P$ uisque mon coeur est mort is presented as the investment of the last orientations of a reading contract established from the beginning, it ends exactly like the incipit, the first words of the text are the same as the last, the anaphora "I hear, I hear the sound of their footsteps " served as an opening as a clausula. The epilogue is constructed in the same form as the incipit: poems with superimposed short sentences, which reveals a diegetic circularity. In the incipit, Nadir, the narrator's son is killed instead of someone else, at the end of the story, Hakim is killed instead of Nadir's murderer. Thus, the doors of the misfortune of the tragic loss of a son will open on another mother, who will undoubtedly experience the same sufferings and the same pains, and will live the same adventure as Aida. So the work is done, the circle is closed and the wheel continues to turn.

\section{The will to live in the autobiography}

For Salwa Tazi, autobiographical writing has the power to repair, almost in the literal sense of the word, it fills silences, connects and sews up parts of life. In his journal, mourning is not endless, it is accomplished through writing. She explains, in a few ways, the reasons why she chose to write :

To distance myself from this appalling slice of my life, I write. From victim, I become screenwriter. Writing gives me a certain distance which gives me unspeakable joy. It allows me to observe my character from afar. The grieving mother who surrenders, delivers me. Wounded, aggrieved, she reveals her suffering in an explosion of words, with more or less contradictory feelings. That tearful mom over there fighting her deep pain is one step ahead of me. (Salwa Tazi, Diary of a Grieving Mother. P.149)

Indeed, if the novel, since my heart is dead, is $a$ fantasy, fears of the author (an Algerian mother) and the reader (the other Algerian mothers), Salwa Tazi's diary is rooted in reality, at its origin there is the death of a " real" child. In this case the autobiography work differently c $\mathrm{O}$ side of both the author and the reader. It is about the death of a real individual, which changes everything : the author and the reader are confronted with the scandal of the real death and not of the fictitious death. It is therefore significant that several novelists 
switch to autobiography to tell the story of their loved ones. Annie Ernaux, at the beginning of La place, explains her choice of genre by advancing that "Subsequently, I started a novel in which he [her father] was the main character. Feeling of disgust in the middle of the story. Recently, I know that the novel is impossible. » (Ernaux, Annie. La Place . P.23 ). Salwa Tazi , facing e to the actual death of a loved one, afraid of seeing disappear $\hat{i}$ be a part of his past, writing thus to save role that past. Memories, and especially those with her son, fill her mourning story. The goal is to keep a form of life for the lost being, but also for oneself. Hence the strongly dental dimension of the story of mourning : by questioning oneself about the dead being, one questions oneself about oneself.

In a way, mourning story is unique, in charge of telling the necessarily unique death of a loved one, death can not be told twice, explains Annie Ernaux about his father in $U$ do woman : " I cannot describe these moments because I have already done it in another book, that is to say that there will never be any other story possible, with other words, another sentence order. »(Ernaux Annie. A woman . P.73)

You only die once, so to speak, in the autobiography. This uniqueness of the autobiographical mourning story proves that the work of mourning finds, at least in the story, an end. Indeed, the autobiographical pact inscribed, according to Philippe Lejeune[2], the reader in the text. It is the horizon of writing. The autobiographer enters into a sort of contract by which he establishes the author / narrator / character identity and undertakes to tell, as faithfully as possible, his life or part of his life. It is not surprising to see autobiographers receive a lot of letters (especially through social networks) concerning their mourning texts. We notice that what the reader does above all is thank the autobiographer for this gift of reading, as well as for the possibility of identification and consolation.[3]. If Maïssa Bey refers us, in a way, to our deep fears, Salwa Tazi, by putting if this is not an end point to her mourning, at least an end point to her story, tells the reader that well continue to live. And if the first text ceaselessly repeats a deadly loss without compensation, the second tries to repair the loss by paying homage to the deceased and by saving through writing what risks disappearing with him.

In fact, many are the theorists who have formulated psychoanalytic theories to try to understand the grieving process.[4], several studies have focused on the number of stages through which the bereaved can go through to achieve their bereavement. This number varies, overall, between three and seven phases, but it should be ISSN: 2456-7620 noted that the theme is very popular, and that despite the numerical difference of these stages; we retrouv ons the same features in the same order in many psychoanalyst s. Indeed, Isabelle Delisle, in her book: survive au mournement : integrating loss (1987), proposes a tripartite division of the work of mourning: the critical stage, the crucial stage and the creative stage. This study is distinguished by the simplicity of the names and the clarity of the steps.

In addition, Julia Kristeva sums up all these stages in one sentence : "Naming suffering, exalting it, dissecting it into its smallest components is undoubtedly a means of reducing mourning. To indulge in it sometimes, but also to exceed it, to move on to another less noisy one. »( KRISTEVA Julia, Black Sun, Depression and Melancholy. P.265) .

The first step occurs when the bad news is announced; the rest find themselves in the obligation to face reality, and first of all it is the language that disappoints them; we notice a certain fear in Salwa Tazi of using the word " death ", which is substituted by three dots of suspension " Hany est ... " (Salwa Tazi. Diary of a grieving mother. p7). Lest validate, e lle attempts throughout his newspaper to avoid this cruel word; as well as to name the dead by their name ; which is substituted by the abbreviation: the "DCD" (Salwa Tazi. Diary of $a$ grieving mother. p21). At this stage, the mother suffers from a shock at the news of the loss, she thinks qu'ell e dream and refuses to accept the conditions caused ant this unbearable pain. In addition to intense feelings of guilt and remorse because of the bad things that have been made and which appear to have led to the loss irréver sible. The pain causes this woman to feel guilty and considers herself responsible for the loss.

I imagine Hany by the beach, he's... how to put it ? I ca n't. Maybe he was on a cliff? Why? His image fades. "Hany is..." " I build a thousand scenarios and I kill myself a thousand times. I blame myself and I blame myself for my negligence. What an unworthy mother! Let her child go to death! I feel guilty and I struggle to go back in time and come to the rescue of my child. (Salwa Tazi. Diary of a grieving mother. P10).

According to psychoanalysts, the second stage, said to be crucial, takes place in two stages: selfobservation and the dissipation of suffering. Writing allows you to observe yourself, to contemplate yourself suffering, panting day after day. The words are sometimes elegiac sometimes reasonable, sometimes both are 
present. The lexical field of melancholy rubs shoulders with the establishment of the construction of a pleasant universe, but it is only reason and the desire to create that delirium Salwa Tazi from the oppression of mourning. This phase is distinguished by the multiple attempts to relate to reality, these pulses of life push this bereaved mother to rediscover the activities that were dear to her ; work reminds us of reality, everyday life and social function.

At $\mathrm{S}$ alwa Tazi, the last stage, called creative, is the reorganisation of life which gives hope again. This mother tries to rebuild her space without her child, by establishing new projects. This stage is also expressed by the return of the life drive in everyday life, which can be read in the enthusiasm of a writing project, it is characterized by the acceptance of the loss of the deceased. A hus, after the changes that have occurred in her life, Salwa Tazi realize that the human being is only a front mour ir, and demonstrates the way that e 1 the no longer part of the individual 's mortals who ignore their condition. From the experience of death, el s e draws changes and positive aspects : The image of death (which is not the same) must internalize and MOI must be freed of the weight of mourning plan for reconstruction.

My pain will not be silent. It will flower to add to the bouquets of beneficent words, which accompanied me during this ordeal. I draw my strength from the language of the wise [... ]. It's my turn to transmit them in my own way and scatter them here and there, so that they perfume our life with a subtle and pure fragrance. Everything that awakens my conscience helps me to understand life, to explain death and to accept my fate with dignity, challenges me. May you discern in it a little comfort, consolation and healing for the soothing of the soul, as I myself have found. (Salwa Tazi. Diary of a grieving mother. P329)

\section{CONCLUSION}

It turns out, therefore, that Salwa Tazi makes an autobiographical pact and a referential pact and commits to a form of sincerity. On the other hand, Maïssa Bey has no contract, she wrote about the death of the son, while hers is alive and well. The romanciè $\mathrm{r} e$ a chewed his sentence without interlocut eur, while autobiography kept always on the horizon of his writing a reader, registered as him in the text by the pa ct autobiographical, with whom el s e shared in her sorrows. Even if this analysis is valid for a large number of autobiographical texts, it seems interesting to us to point out that certain particular cases prove the contrary.

\section{REFERENCES}

[1] Barthes Roland. 2009, Journal de mourning, Paris, Editions du Seuil. p 288

[2] Beckett Samuel. 01/07/1957, $F$ in part, Editions de $\underline{\text { Minuit }} \cdot \mathrm{p} 112$

[3] Delfos Martine. 2000 The elusive parent and 'Emergency 'é write. Amsterdam, Rodopi edition. $\mathrm{p}$ 485

[4] Delisle Isabelle. 1994, Surviving mourning : the integration of loss, Paris : ed Pauline. p 254

[5] Duperey, Anny. 1993. I am writing to you, Paris: Seuil, Coll. "Points ». p 240

[6] Francis Scott Fitzgerald. 1963, La fêlure Paris, Folio. P365

[7] Jean-Paul Sartre. 1948, What is literature? Paris, Editions Gallimard. P 238

[8] Jean-Philippe Miraux, Autobiography, self-writing and sincerity, Paris, Éditions Armand Colin. p 127

[9] Judith Butler. 2007, The story of oneself, Paris, PUF.p 152

[10] KRISTEVA Julia. 1987, S black oleil, depression and melancholy, Paris : Folio, test, Gallimard . p 276

[11] Kübler-Ross. 1977, Death last stage of growth . Montreal: Éditions Québec-Amérique. p 220

[12] Lejeune Philippe. 1998, les brouillons de soi, Paris : Seuil. p 384

[13] Maïssa Bey .2010, Since my heart is dead, La Tourd'Aigues, Editions de l'Aube . p 184

[14] Nys-Mazure, Colette. 2005. The new child, Paris: Bayard. p 77

[15] Sigmund Freud. 1968, Mourning and melancholy in Métapsychologie, Paris, Gallimard.p 192

[16] Tazi Salwa. Mai 2015, J journal of a grieving mother, Casablanca Edition Fennec. p 342 